Dokuz Eylül Üniversitesi-Mühendislik Fakültesi

Fen ve Mühendislik Dergisi

Cilt 20, Sayı 60, Eylül, 2018
Dokuz Eylul University-Faculty of Engineering Journal of Science and Engineering Volume 20, Issue 60, September, 2018

DOI: $10.21205 /$ deufmd.2018206076

\title{
Hazır Giyim Endüstrisinde Çalışan Tasarımcıların Sürdürülebilir Modaya Yönelik Yaklaşımları
}

\author{
Bahar TİBER $^{* 1}$, Sibel YÜCEL ${ }^{2}$ \\ Ușak Üniversitesi, Mühendislik Fakültesi, Tekstil Mühendisliği Bölümü, 64200, Ușak. \\ ${ }^{1}$ (ORCID: 0000-0001- 7145-9327) \\ 2(ORCID: 0000-0002-0646-4071)
}

(Alınış / Received: 20.01.2018, Kabul / Accepted: 18.07.2018,

Online Yayınlanma / Published Online: 15.09.2018)

Anahtar Kelimeler Özet: Hızla artan dünya nüfusu ve sürekli gelişim gösteren

Moda tasarımcisı,

Sürdürülebilir moda,

Hızlı moda,

Yavaș moda,

Hazır giyim

sanayileşme, insanoğlunu daha fazla üretim yapmaya ve tüketmeye sürüklemektedir. Üretim ve tüketim faaliyetlerinde meydana gelen bu hızlı artış dünyanın geleceğini tehdit etmekte, çevrenin kirlenmesine, doğal kaynakların azalmasına ve giderek yok olmasına neden olmaktadır. Sürdürülebilir moda kavramı, tekstil ve hazır giyim sektöründe hızlı üretimin yol açtığı problemlere alternatif bir çözüm olarak, ekolojik hayata zarar veren giysilerin üretimine, üretimde çalışan işçilerin uğradıkları haksızlıklara, gereksiz tüketime karşı ortaya çıkmış ve son zamanlarda dikkat çeken bir konu haline gelmiștir. Bu yaklașımın bir diğer amacı ise yüksek kaliteli giysiler üreterek düşük üretim rakamlarıyla çevre dostu geri dönüştürülebilir ürünler tedarik edilmesini sağlayarak moda endüstrisini yavașlatmaktır. Bu çalıșmada hazır giyim firmalarında çalışan tasarımcıların; hızlı moda, sürdürülebilir moda, yavaş moda, ekolojik moda, eko-etiket ve geri dönüşüm kavramlarına karşı bilgi düzeylerinin, bakış açlarının ve farkındalık durumlarının öğrenilmesi amacıyla anket formu hazırlanmış olup Türkiye'de rastgele olarak seçilen hazır giyim fabrikalarında çalışan tasarımcılara online olarak uygulanmıştır. Anket çalışması rastgele seçilmiş hazır giyim firmalarından çeşitli yaş, cinsiyet ve eğitim durumuna sahip toplam 30 tasarımcıya uygulanmıștır. Elde edilen sonuçlar değerlendirilmiș, katılımcıların bilgi ve bilinç düzeyleri öğrenilerek bu konulara karşı düşünce ve algıları belirlenmiş olup önerilerde bulunulmuştur.

\section{Approaches of Designers Working at Ready-to-Wear Industry to Sustainable Fashion}

Keywords

Fashion designer,
Abstract: Rapidly increasing world population and industry that has demonstrated perpetual development have been leading 
Sustainable fashion, Fast fashion, Slow fashion, Ready-to-wear human being to more production and consumption. This rapid increase taking place within the activities of production and consumption is threatening the future of the world, causing the pollution of environment, decreasing the natural sources and their consequent depletion. The concept of sustainable fashion has emerged against the production of clothes damages ecological life, the injustices of the workers working in production, and unnecessary consumption, as an alternative solution to the problems caused by fast production in the textiles and ready-towear sector and it has become a remarkable issue in recent times. Another objective of this approach is to slow down the fashion industry by producing highly qualified garments with low production quantities with the supply of environmentally-friendly recyclable products. In this study, a questionnaire was prepared and implemented online to randomly selected designers working in clothing companies in Turkey, in order to learn the knowledge, perspective and awareness of the designers working in clothing companies about concepts such as fast fashion, sustainable fashion, slow fashion, eco fashion, eco-label and recycling. The questionnaire was applied to a total of 30 designers of various age, gender and educational status from randomly selected apparel companies. The obtained results were evaluated, the participants' knowledge and the level of consciousness learned, their opinions about this issue and perceptions were determined and suggestions were made.
*Sorumlu yazar: bahar.tiber@usak.edu.tr

\section{Giriş}

Dünya nüfusunda meydana gelen artış, teknoloji, gelişen sanayileşme, yeterli olmayan doğal kaynakların bilinçsizce tüketilmesi çevresel sorunların oluşmasına neden olmaktadır. Tüketim çılgınlığı doğal kaynakları yok etmekte ve doğal hayatı olumsuz etkilemektedir $[1,2,3]$. Bu durum ancak doğal kaynakların kendiliğinden yenilenebilmelerine olanak tanıyacak hızda kullanılmasına olanak sağlayan sürdürülebilir bir yaklaşımla önlenebilir [4]. Meydana gelen bu gibi sorunların çözüme kavuşması amacıyla diğer sektörlerde olduğu gibi hazır giyim sektöründe de sürdürülebilirlik önem kazanmıştır [5].

Rekabetin kendini en çok hissettirdiği sanayi dallarından birisi olan tekstil ve hazır giyim sektöründe mevcut sistem hızlı ve sürekli üretime dayanmaktadır [6,5]. Tüketicilerin ihtiyaçlarını karşılamakla birlikte yeniyi ve farklıyı amaçlayan moda akımlarının hızlı döngüsüne göre üretim yapıldığında ürünlerin kullanım süreleri kısalmakta ve firmalar ürünlerinin olabildiğince hızla çevrilmesini istemektedirler [5]. Çünkü her koleksiyon döngüsünde kar eden üretici firmalar ürün döngüsünü hızlandırarak daha fazla kar elde etmek istemektedir. Bunun temelinde ise hızlı moda olgusu yatmaktadır [7].

\subsection{Hızlı moda}

Hızlı moda kavramı, tasarımdan mağazaya ürünlerin hızlı üretimi sürecine dayalı ve piyasanın gereksinimlerine kısa sürede cevap veren bir iş modelini ifade etmekte olup bütün dünya endüstrisini ele geçirmiştir [8]. 
Hizlı moda, son zamanlarda ucuz moda haline gelmiş, bu da hızlı tüketilebilir bir moda meydana getirmiștir. Yeni olan bir ürünün bu denli hızlı eskitilmesi, çok fazla tüketime ve bunun ortaya çıkardı̆̆ sosyal, ekonomik ve çevresel problemlere neden olmaktadır. Ayrıca bugün beğenilerek satın alınan bir ürün kısa süre sonra modası geçmiş bir atık haline gelmektedir $[9,10]$.

Tekstil ve hazır giyim endüstrisinde sözü edilen bu sorunların azaltılması için ve daha sonra oluşabilecek problemleri azaltmak adına sürdürülebilirlik kavramı bu sektörde "sürdürülebilir moda" şeklinde kendini göstermektedir.

\subsection{Sürdürülebilir Moda}

Yüksek kaliteli ürünlerin yer edindiği veya geri dönüştürülebilir moda akımı şeklinde de tanımlanan sürdürülebilir moda [10], ekolojik hayata zarar veren giysilerin kullanımına, gereksiz yere yapılan alışverişe, üretimde çalışan işçilerin uğradığı haksızlıklara, gereksiz su ve enerji israfına karşı bir akım olarak ortaya çıkmıştır [2]. Sürdürülebilir moda kapsamında; eko-moda, etik moda, yavaş moda, ekolojik moda, yeşil moda, çevreci moda gibi kavramlar günümüzde birbirlerinin yerlerine kullanılan kavramlardır [11,12]

Çevrede meydana gelen olumsuzlukları en aza indirmekle birlikte, insanlara ve topluma faydayı en üst düzeye çıkaracak şekilde tasarım ve üretim şeklinde tanımlanan eko-moda; hızlı moda akımının ve eğilimlerin etkisi sonucunda gerektiğinden daha fazla tekstil üretiminin ekonomik kaynaklara, çevreye ve doğaya verdiği zararı önlemeyi amaçlamaktadır. Sosyal boyutta ise, sektörde çalışan işçilerin elverişli ve uygun şartlarda çalıştırılmasına destek veren bir akımdır $[13,10]$.
Etik moda, organik liflerin kullanılması ile işçilere ve çevreye en az zarar veren ürünler ile adil ticaret prensiplerine bağlı ve iyi çalışma şartlarında üretilen moda giysiler olarak tanımlanmaktadır [2]. Etik moda alanında çalışmalar yapan moda tasarımcıları; sürdürülebilirlik kavramını önemli duruma getirmeyi, organik üretimi yaygınlaştırmayı, bölgesel üretimi desteklemeyi ve sosyal sorumluluğa dikkat çekerek tüketici grupları içerisinde farkındalık meydana getirmeyi amaçlamaktadır [14,15].

Yavaş moda hareketinin temel felsefesi ise, uzun süreli giyilebilecek ve raflarda uzun süreli yer edinecek, kalitesi yüksek, modası geçmeyecek ürünler üretmektir. Bu üretimi yerel kaynaklarla, yerel moda tarzlarıla ve doğal malzemelerle üretmek hedeflenmektedir. Yavaș moda hareketi tüketicilerin giymiş oldukları giysinin kaynağı ve hammaddesi ile ilgili düşünmelerini de sağlamayı amaçlamaktadır. Ürünün kim tarafından üretildiğini, neyi satın aldıklarını ve bu gibi bilgilerin ürünün kalitesini nasıl etkilediğini sorgulatarak sosyal ve çevresel sorumluluk hakkında alternatifler sunmaktadır $[16,17]$.

Uzun ömürlü ürünler, "daha az kaynak tüketimi" ile sürdürülebilir bir yaklaşım olarak görülebilir. Uzun ömürlü ürün tasarımı konsept, form, detaylar ve materyal kalitesinin nasıl farklılı meydana getirdiğine vurgu yaparak tasarımın değerini doğrulamaktadır. Tasarımcı bir ürün tasarlarken o ürünün kısa zamanda, örneğin 6 ay sonra demode olacağını bilerek tasarlaması ile onun nesiller boyu saygıyla ve dikkatle kullanılabileceği duygusu ile tasarlaması, tasarımcılar için büsbütün iki farklı yaklaşım şekli oluşturmaktadır. Tasarımcının ürünü üretmeden önce uzun ömürlülük kavramını göz önünde bulundurarak tasarım sürecine başlaması, uzun dönemde fark meydana getirebilecek anahtar soruları 
müșterisine ve kendisine sormasını sağlayacaktır [18].

Sürdürülebilir tasarımlar yapabilmek için tasarım süreci boyunca bir tasarımcının kendisine yöneltmesi gereken birtakım sorular şöyledir [19]:

-Kumaş iyice incelenip analiz edildi mi? -Yaratılmak istenen giyside bu kumaşın hepsi nasıl kullanabilir?

-Kumaş ve giysi arasında ne tür bir ilişki var?

-Eğer bir desen ya da doku var ise; parçalar arasındaki en büyük boşluk veya "artık" nerede olușmaktadır?

-Yaratıcılık ve olasılıklara yeterince açık miyım?

-Bu tasarımda nerelerde kisitlamaya gitmek artıkları azaltır?

Ayrıca tasarımcıların sürdürülebilir ürünler tasarlamanın yanı sıra ürünlerin üretim aşamasından üretim sonuna kadar maksimum seviyede sürdürülebilir olmasına dikkat etmeleri vurgulanmaktadır.

Modanın değișen ve dinamik yapısına uygun olmayan sürdürülebilirliği modaya yansıtmak, iç içe geçirmek tasarımcıların ve moda sektörünün elindedir. Tasarımcı bir ürünü tasarlarken yalnızca süsleme, görsel güzellik ve bol malzeme düşünceleri ile tasarlamamalı; kaynaklara, çevreye, gelecek kuşakların haklarına ve ekonomiye fayda sağlamanın yanında topluma da bu duygu ve düşünceleri yansıtmalıdır. Endüstrinin daha sürdürülebilir bir moda oluşturma eylemini benimseyerek, geçerli uygulamaları denetlemesi gerekmektedir. $\mathrm{Bu}$ denetleme üretim sürecinin tasarım sürecinde başlamalıdır. [19]. Atıkların değerlendirilmesi ve tasarlanması konusunda düşünen, sorgulayan, geri dönüştüren-onaran, tekrar kullanan, azaltan, motivasyonu yüksek tasarımcılar gerekmektedir. Tasarımcılar söz konusu atıklara bu şekilde yaklaşarak kullanım ömrü biten ürünlerin farklı bir yaşam döngüsü içerisinde yer almasını sağlamaktadırlar [20]. Yani bir tasarımcı tasarıma getirdiği çözümler ile bir ürünün yaşamını uzatabilmelidir [21]. Bu konu ile ilgili çalıșmalarda bulunan moda tasarımcllarından Kosuke Tsumura; atölyesinde eskiyen iplikleri, eldivenleri, kumaşları, değerlendirmektedir. Tasarımcı 1994 yılında başlatmış olduğu "Final Home" isimli çalıșmasında, her geçen yıl daha da kötüye giden doğal yaşama dikkat çekmekte, giderek azalan doğal kaynaklarımızı korumamı gerektiğini vurgulamaktadır [22].

Son yıllarda sürdürülebilir yaklaşımları dünyaca ünlü markaların da uygulamaya başladıkları görülmektedir. Sürdürülebilirlik ile ilgili etkin bir şekilde çalışma sürdüren hazır giyim markalarından birisi olan H\&M firması, kullanılmayacak durumdaki eski tekstil ürünlerini toplayarak özel işleme tesislerinde sınıflandırmaktadır. İyi durumdaki ürünler ikinci el kullanıma sokulmakta, yıpranmış durumda olanlar ise başka tekstil ürünleri olarak yeniden hayat bulmaktadır. Ayrica dolgu ya da yalıtım malzemesi olarak da kullanılmaktadır. Bu sayede H\&M firması hem üretim için hammadde elde etmekte hem de geri dönüşüme destek sağlamaktadır [23, 24]. Gönüllü kuruluş olan TRAID, TRADE Remade markası adı altında bir grup yenilikçi genç tasarımcı grubu ile ikinci el giysileri kişiye özel moda parçalara dönüştürmektedir [18]. Spor giyim üreticisi Patagonia, uzun yıllardır çevreci geçmişi olup 10 yıldır tüketici kitlesinin oluşturmuş olduğu atıklarla yüksek kaliteli geri dönüștürülmüș giysi üretmektedir. Örneğin; poliester otomobil ön panellerinden geri dönüştürülen poliester lifleri ile olușturmuş olduğu özel dokuma ceketleri kullanıma sunmuştur [18]. Nike firmasının üretmiş olduğu formaların imalatında \%100 geri dönüştürülmüş PET şişe kullanılmaktadır 
[25]. Levi's markasının üretmiş olduğu jean pantolonlar $\% 29$ oranında tüketici sonrası oluşan atıklardan geri dönüştürülmüş PET şişe içermektedir [26]. Bir diğer hazır giyim markası olan Adidas bugüne kadarki en sürdürülebilir ayakkabı olarak Fluid Trainer'ı tanıtmıştır. Atık miktarı azaltılacak şekilde tasarlanmış olan bu ayakkabının üst kısmında $\% 50$ oranında geri dönüștürülmüș materyal diğer kısımlarında ise $\% 10$ veya $\% 20$ oranında geri dönüştürülmüş materyal bulunmaktadır [27]. İngiliz moda markası olan Marks\&Spencer, geri dönüștürülmüș malzemelerden yapılmış özel bir takım elbise üretmiştir [28]. Yeşim Tekstil; Türkiye'de pamuklu kumaşta geri dönüşüm uygulayan ilk firmalardan biridir. "Yeşim Recycle" adıyla üretmiş olduğu bu ürünlerde maksimum \%50 oranında geri dönüşümlü iplik kullanmakta ve bu kumaşla pamuğun yetiştirilmesinin zorluğunu göz önüne alarak, mevcut kaynakların yeniden değerlendirilmesini hedeflemektedir. Böylelikle çoğunlukla kalın ipliklerin kullanıldığı halılarda uygulanan geri dönüşüm tekniği artık daha ince ipliklerle tişörtlerin üretiminde de gerçekleştirilmiştir [29].

\section{4 İlgili Çalışmalar}

Sürdürülebilir moda kapsamında yapılan akademik çalışmalar kısaca şu şekildedir:

Türkmen (2009), tekstil ve moda tasarımı açısından sürdürülebilirlik ve dönüşüm konusunda yaptı̆̆ $\quad$ çalışmada; sürdürülebilir bir gelecek sunmaya ve sürdürülebilirlik kavramı üzerine bakış açısı oluşturmaya çalışmıştır. Bunun yanı sıra tekstil ürünlerinin tasarım, üretim ve kullanım aşamalarında geleneksel düşüncelerin ötesine geçen uzun ömürlü sosyal ve çevresel bilinç oluşturabilmenin çeşitli yollarını önermek amacıyla gereken değişim için tasarımın önemini ortaya koymuștur. Çalışmanın sonucunda moda endüstrisi ve sürdürülebilir bir tekstil için kısa ve uzun vadede ulașılması gereken hedefler üzerinde durulmuştur [18].

Niinimaki ve Hassi (2011) sürdürülebilir ürünler tasarlamaya yönelik, ürünün kullanım ömrünü arttıracak tasarım stratejilerinin üzerinde durmuşlardır. Ürünlerin yarı mamul șeklinde tasarlanıp, geri kalan kısmının giysinin kullanıcısının tamamlamasına firsat vererek, kullanıcının giysiyi kişiselleştirmesi yoluyla kişi ile giysi arasında özel bir bağ kurarak giysinin daha uzun süre kullanılabileceğini belirtmişlerdir. Ürünlerin ilk hali üzerinde eklemeler ya da güncellemeler yapmaya olanak tanıyan modüler ürünler tasarlamanın da giysinin kullanım ömrünü arttıracağını dile getirmişlerdir. Ayrıca yavaş tasarım yaklaşımıyla dayanıklı ve sürdürülebilir materyaller kullanılarak yüksek kalitede ve yüksek etik değerlere sahip uzun ömürlü ürünlerin üretilebileceği ifade edilmiştir. Ortak tasarım yaklaşımı ve açık kaynaklı tasarımlar ile kullanıcının tasarım sürecine kısmen ya da tamamen katkısının ürün memnuniyetini arttıracağl belirtilmiştir. Dijital baskı, nakış ve lazerli kesim makineleri ile dijital dokuma makinelerinin tüketicilerin bireysel tercihlerini ve ihtiyaçlarını gerçekleştirmek için geniş fursatlar sunduğu ve kişiye özel üretimin yapılabileceği dile getirilmiştir. $\mathrm{Bu}$ teknikler ile endüstriyel ölçekteki üretime kıyasla malzeme kullanımında tasarruf sağlanacağı; daha fazla üretim yerine sadece mevcut siparişlere dayalı üretim yapılacağl belirtilmiştir. Ürünün tamiri, modifiyesi ya da kiralanması gibi servislerin olmasının ürünün daha uzun süre kullanılmasını sağlayacağı belirtilmiştir [30].

İşmal ve Yıldırım (2012), tekstil tasarımında çevre dostu yaklaşımlar içerikli çalışmasında, ekolojik tekstil ve 
tasarım yaklaşımına, bir tasarımcının ürün tasarlama sürecinde ne gibi ölçütleri göz önünde bulundurması gerektiğine ve tasarımcların sorumluluğuna değinmişlerdir. Tasarımlarda organik olarak üretilmiş doğal lifler ve yenilenebilir kaynaklardan üretilmiş veya geri dönüșümle kazanılmış kimyasal lifler tercih edilmesini önermişlerdir [20].

Joy ve diğer. (2012), Hong Kong ve Kanada'da hızlı moda tüketicisi olan 2035 yaş arasındaki erkeklerle kadınların sürdürülebilirlik, hızlı moda ve lüks moda algılarını karșılaștırmıșlardır. Söz konusu tüketicilerin stil ve moda hakkındaki fikirlerini öğrenmeye yönelik yapılan çalışmada, onların tüketime yaklaşımlarındaki sorunları öne çıkarmaya çalışmışlardır. Toplanılan bilgiler doğrultusunda sürdürülebilir modanın onlar için bir önem arz etmediği, ayrıca gençlerin moda ve sürdürülebilirliği birbirinden ayrı değerlendirdikleri gözlemlenmiștir. Ayrıca yapılan çalıșmada "kullan-at ve sınırlı dayanıklılık" ibaresi ön plana çlkmış olup bu ibarenin tüketicilere tercihlerini kolay değiștirme imkanı sunduğu düşünülmektedir [13].

Göksel ve Yanmaz (2012), modası geçmiş giysilerin yeniden kullanımına yönelik çalışmalarında, modası geçmiş eski olarak tabir edilen, bir kenara atılmış giysiler ile yeni tasarımlar oluşturmayı amaçlamışlardır. Bu çalışmada, 18-25 yaș arası yüksekokul öğrencilerinin giysi alımına ve kullanımına yönelik istatistiksel araștırmaya dayandırılarak modası geçmiş giysiler için, yeni kumaş, malzeme ve aksesuarla yenileștirme ve yeniden kullanılması yönünde özgün öneriler getirilmiştir [31].

Kılıç (2013), giyim sektöründe meydana gelen üretim atıklarını sürdürülebilir moda yaklaşımı ile değerlendirmiş ve Ankara'da bulunan 32 hazır giyim işletmesinde bu atıkların nerelerde değerlendirildiği konusunda kapsamlı bir araştırma yapmıştır. Bunun yanında tasarım ve yaratıcılık değeri yüksek 10 adet giysi tasarımından oluşan ve "Artıklar, Artık Çöp Değil" konulu bir koleksiyon hazırlanmıș ve sektörün sürdürülebilir moda kavramına farkındalığının artırılmasına dikkat çekilmiştir [19].

Jung ve Jin (2014), ölçek geliştirme yolu (anket) ile yavaş modanın altında yatan boyutları aramak için yapılan ilk çalışmalardan birisidir. Yavaş modanın yapısı 5 faktörle açıklanmıştır. Belirlenen beş boyut (eşitlik, özgünlük, yerelcilik, sınırlılık ve işlevsellik) yavaş modanın çevresel sürdürülebilirlikten daha geniş bir kavram olduğunu açıkça gösterdiği sonucuna ulașilmıștır. $\mathrm{Bu}$ boyutların yavaş modanın tanımı için teorik bir temel oluşturabileceğini ileri sürmüşlerdir. Ayrıca yavaş modanın ABD iç giyim üretimini ve yerel ekonomileri teşvik etmesinde yararlı olabileceği belirtilmiştir [32].

Shen (2014), sürdürülebilir moda tedarik zincirini incelemiș ve örnek firma olarak H\&M firmasını ele almıştır. Çalışmada, H\&M'in sürdürülebilir çalışma uygulamaları ve tedarikçi seçimi üzerinde durulmuștur. H\&M'in eko-materyallerin kullanımı ve teşvik edilmesi, sürdürülebilir bilince sahip ülkelerde sürdürülebilir üretimin yapılması, daha az emisyon ve enerji kullanımı ile yeşil dağıtım yaklaşımı, yeşil perakendecilik ve tüketicilerin eğitimini kapsayan "Bilinçli Eylem" (Conscious Action) isimli sürdürülebilirlik hareketi incelenmiştir. Tedarikçileri bakımından, 151 ülke insan refahı, çevresel refah ve ekonomik refah açılarından sıralanmıș, ancak veri analizinde 10 'dan fazla tedarikçinin bulunduğu ülkelere odaklanılmıştır. Yapılan istatistiksel analiz sonucunda H\&M'in tedarikçilerini insan refahının düşük olduğu ülkelerden seçtiği, insan refahının yüksek olduğu ülkelerde daha 
fazla stok bulundurduğu ve belirli bir ülkede online alışveriş mağazasını kullanıma sunarken, çevresel refah yerine, insan refahı ve ekonomik refah düzeylerini dikkate aldığı belirlenmiştir. [33].

Hahn ve Palomo-Lovinski (2015), çağdaş moda tasarım eğitiminde sürdürülebilir uygulamanın önemini ortaya koymayı amaçlamışlardır. $\mathrm{Bu}$ amaçla moda endüstrisinde aktif olarak çalışan tasarımcıların modada sürdürülebilirlik hakkındaki genel fikirlerini ve kendilerinin mevcut sürdürülebilir uygulamalarını öğrenmek için anket çalışması yapılmıştır. Katılımcıların yüzde 87'si sürdürülebilirliğin çözülmesi gereken bir sorun olduğunu belirtmiş, bunun yanı sıra sürdürülebilirliğe en çok hangi alanlarda ihtiyaç duyulduğunun sıralanması istendiğinde moda tasarımcıları sırasıyla; \%39,4 ve \%33,3 oranında gıda ve taşımacılığı seçerken, giyim sektörünün bu siralamada $\% 6,1$ oranında olduğu görülmüștür. Bunun yanı sıra tasarımcların \%75'i tüketicilerin sürdürülebilirliği önemsemediğini ifade etmiştir. Araştırmaya katılan tasarımcıların hiçbirinin moda kariyerlerinde sürdürülebilir uygulamaya aktif olarak katılmadığı gözlemlenmiştir. Anket sonuçları değerlendirildiğinde moda endüstrisinin sürdürülebilirlikle ilgili endişeleri dile getirmedeki etkisinin büyük ölçüde çevresel ve sosyal kaygılarla ilgili gerçek bir bilgisi olmayan yeni mezun olan modacılara bağlı olduğu ifade edilmiştir. Ayrıca sürdürülebilirliğin etik bir zorunluluk olduğunu, karlılık, verimlilik ve estetik kalite eşit ölçülerde hesaba katılmazsa başarılı olunamayacağını dile getirmişlerdir [34].

Ericsson ve Brooks (2015), Avrupa'dan ve Amerika'dan toplanan giysilerin yoksul Afrika ülkelerinde ikinci el olarak satıldığı pazarlardan topladıkları giysiler ile modaya uygun yeni tasarımlar yaparak değer yaratan ve satan Mima-te markasını incelemişlerdir. Çok ucuz fiyata alınan 2 . el bir giysinin yeniden estetik ögelerle tasarlanması başarılı bir sürdürülebilirlik örneği olmuştur. Çalışmada bununla birlikte bu ikinci el giysi pazarlarının o ülkelerin ekonomik gelișmesi üzerindeki etkisi incelenmiş ve bu ikinci el giysilerin ucuz fiyatla satılmasının yerel üretimin rekabetçi gücünü ne kadar etkilediğinden bahsedilmiştir [35].

Mangır (2016), sürdürülebilir kalkınma için yavaş ve hızlı moda başlıklı bir araștırma yapmıștır. Yapılan çalıșmaya göre; hızlı modayı uygulayan hazır giyim firmalarının yavaş moda kullanımını artırmaları gerektiği, sürdürülebilirlik odaklı ve çevre dostu üretimin desteklenmesinin gerekli olduğu sonucuna varılmıștır [12].

Ayanoğlu ve Ağaç (2017) sürdürülebilir modanın tasarım ayağındaki düşünceleri derleyip tartışarak, bu konuya dair farkındalık seviyesini artırmayı ve konu ile ilgili geliştirilebilecek yeni düşüncelerin doğmasına yönelik bir basamak oluşturmayı amaçlamışlardır. Yapılan araștırmada sürdürülebilir moda alanında yapılan tasarım fikirleri analiz edildiğinde, bir kısmının yeni fikirlerin oluşması yönünde basamak görevi gördüğü bir kısmının ise farkındalık meydana getirme düzeyinde kaldığı sonucuna ulaşmışlardır [36].

Daha önce yapılan çalışmalar incelendiğinde Türkiye'de hazır giyim sektöründe çalışan moda tasarımcılarının; sürdürülebilir moda, yavaş moda, etik moda, ekolojik moda, geri dönüșüm ve eko-etiket konularına dair görüş ve düşüncelerinin araştırılmamış olduğu görülmüştür. Tasarımclar üretim zincirinin önemli bir basamağını oluşturmaktadır. Bundan ötürü biz insanları giydiren moda tasarımcılarının; hızlı modanın neden olduğu problemleri bilip bilmediğinin ve 
bu sorunlara karșı ortaya çıkmıș olan sürdürülebilirlik ile ilgili kavramların ne anlama geldiğinin, ne gibi fayda sağladığının ve farkındalık durumlarının belirlenmesinin faydalı olacağı düşünülmüştür. Yapılan bu çalışmada son yıllarda üzerinde durulan sürdürülebilir moda kavramı tasarımcıların bakış açısından değerlendirilmiştir. Hazır giyim işletmelerinde çalışan moda tasarımcılarının sözü edilen konular hakkındaki fikir ve algılarının ne olduğunun belirlenmesi ve bu konulara ilişskin tutumlarının nasıl olacağının öğrenilmesi amaçlanmıştır. Bu amaçla anket formu hazırlanmış ve tasarımcılara online olarak uygulanmıștır. Elde edilen veriler SPSS istatistik programı kullanılarak değerlendirilip tasarımcı kitlesinin bu konulara karșı yaklașımları, bilgi ve bilinç düzeyleri belirlenmiştir.

\section{Materyal ve Metot}

Hazır giyim işletmelerinde çalışan moda tasarımcılarının sürdürülebilir moda, hızlı moda, yavaş moda, ekolojik moda, geri dönüşüm ve eko-etiket kavramlarına ilişkin düşünce ve yaklaşımlarının öğrenilmesi amacıyla 53 sorudan oluşan anket online olarak hazırlanmıştır. Anketin online olarak doldurulacağı web sayfasının linki Ege ve Marmara bölgesinde faaliyet gösteren ve farklı alanlarda üretim yapan (kadın, erkek veya çocuk; dış giyim, iç giyim, spor giyim, triko giyim, çorap vb.) rastgele 95 adet hazır giyim işletmesine, tasarımclarca doldurulmak üzere online olarak gönderilmiştir. $\mathrm{Bu}$ gönderilen işletmelerde çalışan sadece 30 moda tasarımcısı anketi cevaplandırarak katılım göstermiştir. Anket katılımcılarına öncelikle kişisel bilgi soruları yöneltilmiş, bununla birlikte çalışmakta oldukları işletmede tasarımcı olarak ne kadar süredir çalıştıkları, işletmenin ne üzerine üretim yaptığı sorulmuștur. Bunların yanında hızlı moda, sürdürülebilir moda, yavaş moda, ekolojik moda, eko-etiket ve geri dönüşüm konularında bilgi sahibi olup olmadıkları ve bu konulardaki düşünceleri sorulmuştur. Ankete katılan kişilerin verdikleri cevaplar incelenmiș, sonuçlar SPSS istatistik programına göre değerlendirilmiş, elde edilen sonuçlara göre de katılımclların verdiği yanıtlar tablolar halinde sunulmuş, sonuçları yorumlanmış ve önerilerde bulunulmuştur.

\section{Bulgular}

Ankete katılan tasarımcların cinsiyetleri incelendiğinde, \%56,67'sinin kadın, $\% 43,33$ 'lük dilimin erkek olduğu tespit edilmiştir.

Ankete katılan tasarımcı kitlesinin yașa göre dağılımı Şekil 1'de verilmiştir. Tasarımcıların yaş dağılımına bakıldığında 31-35 yaş aralığına sahip $\% 30$ oranında tasarımcl olduğu belirlenirken, 36-40 yaş aralığında ise $\% 33,33$ oranında tasarımcı olduğu tespit edilmiştir.

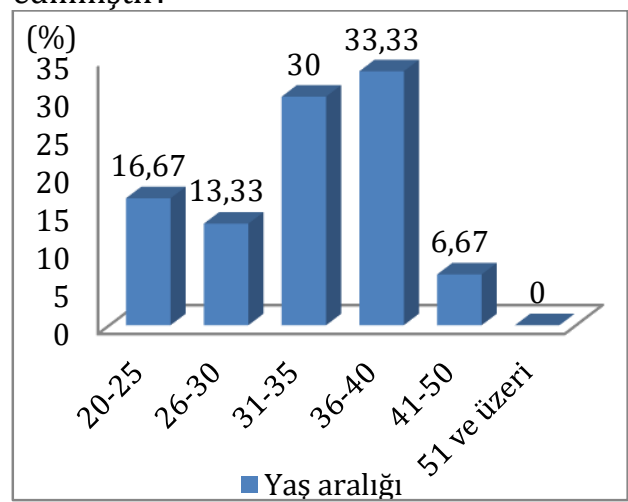

Şekil 1. Tasarımcıların yaşa göre dağıılımı

Şekil 2'de tasarımcıların eğitim durumları verilmiştir. Tablodaki veriler ışığında tasarımcıların \%50'sinin lisans eğitimine sahip olduğu görülürken, \%30'unun önlisans eğitimine sahip olduğu saptanmıştır. 


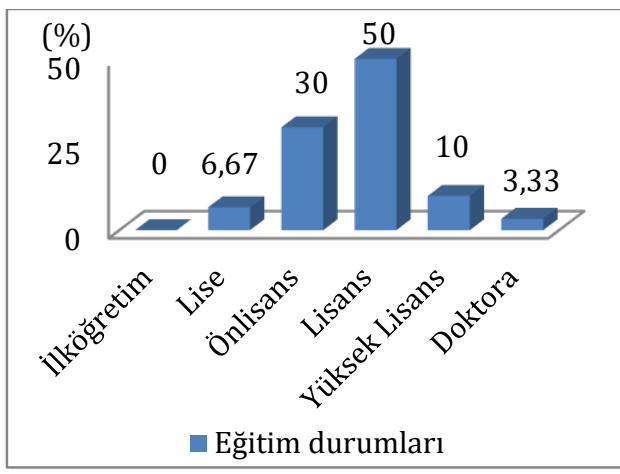

Şekil 2. Tasarımcıların eğitim durumları

Anket katılımcılarının tasarımcı olarak bu meslekte ne kadar süredir çalıștığı Şekil 3'te verilmiştir. Tasarımcl kitlesinin \%40'ının 11-15 yıl arasında, \%33'ünün ise 1-5 yll arasinda hazır giyim sektöründe tasarımcı olarak çalıștığı belirlenmiștir.

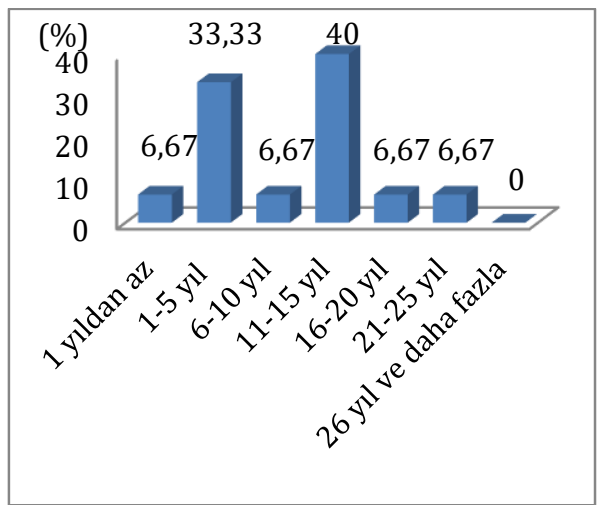

Şekil 3. Tasarımcıların hazır giyim sektöründe tasarımcı olarak çalışma süreleri

Sekil 4'te tasarımcıların bulundukları işletmede tasarımcı olarak ne kadar süredir çalıștıkları görülmektedir. Tasarımcı kitlesinin \%46,67'lik diliminin bulundukları işletmede 1-5 yıl arasında çalıștığı tespit edilirken, \%36,67'sinin 610 yıl süredir çalıştıkları belirlenmiștir.

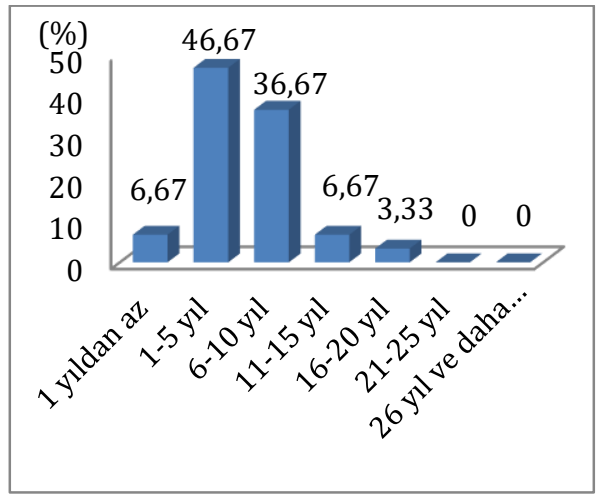

Şekil 4. Tasarımcıların bulundukları işletmede tasarımcı olarak çalışma süreleri

Tasarımcllara yöneltilen bir diğer soru ise bulundukları ișletmenin ne üretimi yaptığı ile ilgilidir. Tasarımcların verdikleri cevaplar göz önünde bulundurulduğunda işletmelerin bayan giyim, erkek giyim, kadın-erkek-çocuk giyim, kadın-erkek-çocuk iç giyim, forma üretimi, spor ürünleri, bayan kaban üretimi, çorap ve triko üretimi yaptığı tespit edilmiştir.

Tablo 1'de tasarımcıların hızlı moda, sürdürülebilir moda, ekolojik moda ve eko-etiket kavramlarına ilişkin bilgi durumları verilmiștir.

Tablo 1. Tasarımcıların hızlı moda, sürdürülebilir moda, ekolojik moda ve eko-etiket kavramlarına ilişkin bilgi durumları

\begin{tabular}{|l|c|c|c|}
\hline \multicolumn{1}{|c|}{ Görüşler } & $\begin{array}{c}\text { Evet } \\
\text { biliyorum }\end{array}$ & $\begin{array}{c}\text { İlk kez } \\
\text { duyuyorum }\end{array}$ & $\begin{array}{c}\text { Daha önce } \\
\text { duydum ama } \\
\text { ne olduğunu } \\
\text { bilmiyorum }\end{array}$ \\
\cline { 2 - 4 } & $\mathbf{\%}$ & $\mathbf{\%}$ & $\mathbf{\%}$ \\
\hline Hızlı moda konusunda fikir sahibiyim & 93,33 & - & 6,67 \\
\hline Sürdürülebilir moda konusunda fikir sahibiyim & 90,00 & 3,33 & 6,67 \\
\hline Yavaș moda konusunda fikir sahibiyim & 76,67 & 10,00 & 13,33 \\
\hline Ekolojik moda konusunda fikir sahibiyim & 83,33 & 6,67 & 10,00 \\
\hline Eko-etiket konusunda fikir sahibiyim & 80,00 & 6,67 & 13,33 \\
\hline
\end{tabular}


Tablo 1'deki veriler incelendiğinde, tasarımcılara hızlı moda kavramı ile ilgili bilgi sahibi olup olmadıkları sorulduğunda tasarımcıların \%93,33’ü bu kavramı bildiğini söylemiştir.

Verilere göre tasarımcı kitlesinin \%90’ı sürdürülebilir moda ile ilgili fikir sahibi olduğunu belirtmiștir. Tasarımcıların \%3,33'ünün sürdürülebilir modayı ilk kez duyduğu belirlenirken, bu kavramı daha önce duymuş olan ama bilgisi olmayan $\% 6,67$ oranında tasarımcl olduğu tespit edilmiştir.

Yavaş moda kavramı hakkında fikir sahibi olan tasarımciların \%76,67 oranında olduğu görülürken, bu kavramı ilk kez duyduğunu dile getiren \%10 oranında tasarımcı mevcuttur. Tasarımcı grubunun \%13,33'lük kısmı ise yavaş moda kavramını daha önce duyduğunu ancak ne olduğunu bilmediğini söylemiştir.

Anket çalışmasına katılan tasarımcı kitlesinin \%83,33'ünün ekolojik moda hakkında fikir sahibi olduğu görülmektedir. Ekolojik moda kavramını ilk kez duyduğunu belirten \%6,67 oranında tasarımcı bulunurken, tasarımcı grubunun \%10'luk dilimi ise bu kavramı daha önce duyduğunu ancak ne olduğunu bilmediğini ifade etmiştir.

Eko-etiket kavramı hakkında fikir sahibi olan tasarımcıların \%80 oranında olduğu görülürken, bunu ilk kez duyduğunu belirten \%6,67 oranında tasarımcı olduğu tespit edilmiștir. Tasarımcıların \%13,33'lük dilimi ise eko-etiket kavramını daha önce duyduğunu ancak ne olduğunu bilmediğini ifade etmiştir.

Veriler göz önünde bulundurulduğunda; tasarımcı kitlesinin büyük bir oranının hızlı moda, sürdürülebilir moda, yavaş moda, ekolojik moda ve eko-etiket kavramları ile ilgili bilgi sahibi olduğu sonucuna ulaşılmıştır. Az bir oran da olsa bu kavramları daha önce hiç duymayan tasarımcıların olduğu ortaya çıkmıştır.

Tasarımcıların hızlı moda, sürdürülebilir moda, yavaş moda ve geri dönüşüm ile ilgili düşünceleri Tablo 2 'de verilmiştir.

Tablo 2. Tasarımcıların hızlı moda, sürdürülebilir moda, yavaş moda ve geri dönüşüm ile ilgili düșünceleri

\begin{tabular}{|c|c|c|c|}
\hline \multirow{2}{*}{ Görüşler } & Katılıyorum & Kararsızım & Katılmıyorum \\
\hline & $\%$ & $\%$ & $\%$ \\
\hline $\begin{array}{l}\text { Tasarımcı olarak hızlı modaya karşı çözüm niteliğinde } \\
\text { olan sürdürülebilir moda uygulamasını doğru } \\
\text { buluyorum. }\end{array}$ & 60,00 & 33,33 & 6,67 \\
\hline Tasarımcı olarak yavaș moda akımını destekliyorum. & 56,67 & 26,67 & 16,67 \\
\hline Tasarımcı dediğin kalite odaklı olmalıdır. & 100,00 & - & - \\
\hline $\begin{array}{l}\text { Hızlı moda demek düşük fiyat ve düşük kalite } \\
\text { demektir. }\end{array}$ & 3,33 & 23,33 & 73,33 \\
\hline $\begin{array}{l}\text { Bir tasarımcı olarak hızlı değișen moda ile ülkeler } \\
\text { arasında giyim kültürünün birbirine benzediği } \\
\text { düşüncesindeyim. }\end{array}$ & 63,33 & 6,67 & 30,00 \\
\hline $\begin{array}{l}\text { Bir tasarımcı olarak hızlı modanın tasarımların } \\
\text { kalitesini ve özgünlüğünü olumsuz yönde etkilediğini } \\
\text { düșünüyorum. }\end{array}$ & 6,67 & 16,67 & 76,67 \\
\hline $\begin{array}{l}\text { Hızlı moda biz tasarımcıları sürekli üretmek zorunda } \\
\text { bıraktığından, gerektiğinden daha fazla çalıșıyorum. }\end{array}$ & 46,67 & - & 53,33 \\
\hline 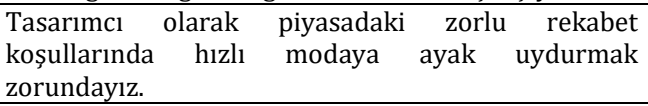 & 100,00 & - & - \\
\hline $\begin{array}{l}\text { Ürünün yaşam seyrinin kısa olması biz tasarımcıları } \\
\text { zor duruma sokmaktadır. }\end{array}$ & 80,00 & - & 20,00 \\
\hline
\end{tabular}


B. Tiber, S. Yücel / Hazır Giyim Endüstrisinde Çalıșan Tasarımcıların Sürdürülebilir Modaya Yönelik Yaklașımları

\begin{tabular}{|c|c|c|c|}
\hline $\begin{array}{l}\text { Bir tasarımcı olarak kimliğimizi sürdürebilmemiz için } \\
\text { bu hızlı değișime ayak uydurmak zorundayız. }\end{array}$ & 100,00 & - & - \\
\hline $\begin{array}{l}\text { Önemli olan tasarladığım ürünlerin talep görmesidir. } \\
\text { Diğer sorunları önemsemiyorum. }\end{array}$ & 80,00 & 3,33 & 16,67 \\
\hline $\begin{array}{l}\text { Kendi stilini oluşturan tasarımcılar genelde hızlı } \\
\text { modaya şüpheli bakmaktadır. }\end{array}$ & 6,67 & 63,33 & 20,00 \\
\hline $\begin{array}{l}\text { Yavaş modanın küreselleşme sorununa karşı çözüm } \\
\text { olabileceğine inanıyorum. }\end{array}$ & 53,33 & 33,33 & 13,33 \\
\hline $\begin{array}{l}\text { Yavaş moda ile geleneklerimize sahip çıkabileceğimizi } \\
\text { düşünüyorum. }\end{array}$ & 16,67 & 56,67 & 26,67 \\
\hline $\begin{array}{l}\text { Tasarımcı olarak uzun süre giyilebilir ve modası } \\
\text { geçmeyecek giysiler üretmeyi seviyorum. }\end{array}$ & 43,33 & - & 56,67 \\
\hline $\begin{array}{l}\text { Tasarımcı olarak uzun süre giyilebilir ve modası } \\
\text { geçmeyecek giysiler üretmeyi tercih ediyorum. }\end{array}$ & 13,33 & - & 86,67 \\
\hline 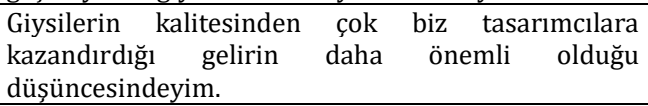 & 80,00 & 3,33 & 16,67 \\
\hline $\begin{array}{l}\text { Yavaş moda konusunda biz tasarımcıların bilinçli } \\
\text { olduğunu düşünüyorum. }\end{array}$ & - & 6,67 & 93,33 \\
\hline $\begin{array}{l}\text { Yavaș moda bütün tasarımcıların benimsemesi } \\
\text { gereken bir akımdır. }\end{array}$ & 30,00 & 60,00 & 10,00 \\
\hline $\begin{array}{l}\text { Bir tasarımcı olarak farklı ürün elde etme konusunda } \\
\text { artık sınıra ulașıldığını düșünüyorum. }\end{array}$ & - & 76,67 & 23,33 \\
\hline $\begin{array}{l}\text { Yavaş moda konusunda biz tasarımcılara eğitim } \\
\text { verilmesi gerektiğini düşünüyorum. }\end{array}$ & 43,33 & 40,00 & 16,67 \\
\hline $\begin{array}{l}\text { Tasarımcı olarak raflarda kısa süre kalan ürünlerden } \\
\text { memnunum çünkü sürekli üretmeyi seviyorum. }\end{array}$ & 53,33 & - & 46,67 \\
\hline $\begin{array}{l}\text { İnternet ile piyasaya sürülen ürünler, güncel } \\
\text { ürünlerin ve tasarım ögelerinin hızlı eskimesine } \\
\text { neden olmaktadır. }\end{array}$ & 46,67 & 53,33 & - \\
\hline $\begin{array}{l}\text { Moda tasarımcıları, hızlı modanın yavaş modaya } \\
\text { doğru değișim göstermesinde rol oynamalıdır. }\end{array}$ & 60,00 & 33,33 & 6,67 \\
\hline $\begin{array}{l}\text { Sürdürülebilir moda ve yavaş modanın } \\
\text { uygulanmasında en büyük görev biz tasarımcılara } \\
\text { düşmektedir. }\end{array}$ & 60,00 & 40,00 & - \\
\hline $\begin{array}{l}\text { Geri dönüşüm malzemelerinden giysi tasarlamayı } \\
\text { seviyorum. }\end{array}$ & 3,33 & - & 96,67 \\
\hline $\begin{array}{l}\text { Giysilerin kalitesinden çok yakışmasının daha önemli } \\
\text { olduğunu düşünüyorum. }\end{array}$ & 83,33 & 6,67 & 10,00 \\
\hline $\begin{array}{l}\text { Bir tasarımcı olarak giysi satın alırken o giysinin geri } \\
\text { dönüștürülebilirliğine bakarım. }\end{array}$ & 6,67 & - & 93,33 \\
\hline
\end{tabular}

Tablo 2'ye göre hızlı modaya karşı çözüm niteliğinde ortaya çıkan sürdürülebilir moda uygulamasını doğru bulan tasarımcı kitlesinin oranının çoğunlukta olduğu tespit edilmesine rağmen, tasarımcıların tümü kimliklerini sürdürebilmek ve piyasadaki zorlu rekabet koşullarında var olabilmek için hızlı modaya ayak uydurmak zorunda olduklarını dile getirmişlerdir.

Ankete katılan tüm tasarımclar, tasarımcının kalite odaklı olması gerektiğini ifade ederken, bunun aksine giysilerin kalitesinden çok kendilerine kazandırdığı geliri önemli bulan, tasarladığ önemli olduğunu ve bunun dışında diğer sorunları önemsemediğini belirten \%80 oranında tasarımcl olduğu tespit edilmiştir. Ayrıca giysilerin kalitesinden ziyade yakışmasının daha önemli olduğu da $\quad(\% 83,3)$ belirtilmiştir. Buradan anlaşılmaktadır ki tasarımcılar için teorik olarak kalite önemlidir ancak uygulamada aynı önem verilmemektedir. 
Tasarımcıların çoğu hızlı modanın; düșük fiyat ve düșük kalite anlamına gelmediğini, tasarımların kalitesini ve özgünlüğün olumsuz yönde etkilemediğini ifade etmişlerdir.

Hızlı moda ile ülkeler arasındaki giyim kültürünün birbirine benzediğini düşünen tasarımcılar çoğunluktayken yavaş moda ile geleneklere sahip çıkılabileceği pek düşünülmemektedir.

Tasarımciların \%46,67'si, hızlı modanın sürekli üretmek zorunda bıraktığından gereğinden fazla çalıștığını dile getirirken, \%53,33'ü sürekli üretmeyi sevdiğinden ürünlerin raflarda kısa süre kalmasından memnun olduğunu belirtmiştir. Ancak yine de \%80'lik bir kısım ürünlerin ömrünün kısa olmasının kendilerini zor duruma soktuğunu ifade etmektedir.

Tasarımcı kitlesinin \%43,33'ünün uzun süre giyilebilir ve modası geçmeyecek giysiler üretmeyi sevmesine rağmen yalnızca \%13,33'ünün bu tarz giysiler üretmeyi tercih ettiği sonucuna ulaşılmıştır.

Kendi stilini oluşturan tasarımcıların genelde hızlı modaya şüpheli baktığı, yavaş modanın bütün tasarımcıların benimsemesi gereken bir akım olduğu ve farklı bir ürün elde etme konusunda artık sınıra gelindiği sorularında tasarımcıların çoğunun kararsız kaldığı görülmüştür. Bu kararsızlığın sebebinin bu konular üzerinde daha önceden düşünüp bir fikir oluşturmadıklarından kaynaklandığı düşünülmektedir.
Tasarımcılar yavaș moda konusunda kendilerinin bilinçli olmadığını kabul etmektedirler. Ancak sadece \%43,33'ü kendilerine bu konuda eğitim verilmesi gerektiğini düşünmektedir.

Hızlı moda anlayışının yavaş anlayışına doğru değişiminde ve sürdürülebilir yaklaşımların moda ve hazır giyim sektöründe uygulanmasinda tasarımcılara büyük rol düştüğünü tasarımcıların çoğu (\%60) kabul etmiştir. Ancak bununla birlikte tasarımclarının tümüne yakın bir kısmı geri dönüşüm malzemelerinden giysi tasarlamayı sevmediklerini ve giysi satın alırken de o giysinin geri dönüştürülebilir olup olmadığına bakmadıklarını ifade etmişlerdir.

Anket çalışmasına katılan moda tasarımcılarının verdikleri cevaplara göre tasarımcıların çoğunluğunun sürdürülebilir moda ile yavaş modaya yönelik pozitif bir tutum sergiledikleri söylenebilir ancak söz konusu kavramların uygulanması noktasında tutumlarının davranışlarına yansımadığ tespit edilmiştir. Bunun sebebinin toplumda olduğu gibi moda tasarımcılarında da yeterli bilinç ve farkındalık düzeyine ulaşılamamış olmasıyla birlikte piyasadaki rekabet koşullarının zorlayıcılığından kaynaklandığı söylenebilir.

Tablo 3'te tasarımclar açısından sürdürülebilir moda kavramının ne ifade ettiği sorusuna verilen cevaplar verilmiştir. 
B. Tiber, S. Yücel / Hazır Giyim Endüstrisinde Çalışan Tasarımcıların Sürdürülebilir Modaya Yönelik Yaklaşımları

Tablo 3. Tasarımcılara göre sürdürülebilir moda kavramı

\begin{tabular}{|l|c|}
\hline Sürdürülebilir moda kavramı & $\mathbf{\%}$ \\
\hline $\begin{array}{l}\text { Giyim sektöründe üretim yapmakta olan işletmelerin üretim sürecinin başından sonuna kadar } \\
\text { tüm işlemlerinde çevreyi düşünerek adım atmasıdır. }\end{array}$ & 20,00 \\
\hline $\begin{array}{l}\text { Giyim sektöründe üretim yapmakta olan işletmelerin sürekli değișen, dinamik ve hızlı } \\
\text { olmasıdır. }\end{array}$ & - \\
\hline Giyim sektöründe küresel yoksulluğu ortadan kaldıracak bir sosyal değişimdir. & 16,67 \\
\hline $\begin{array}{l}\text { Giyim sektöründe atıklar oluştuktan sonra yok etmek yerine oluşmasını engelleyecek önlemleri } \\
\text { almak ve üretim süreci öncesinde ve üretim esnasında doğa dostu davranmaktır. }\end{array}$ & 60,00 \\
\hline Giyim sektöründe dünya için alınması gereken önemli tedbirlerden birisidir. & 3,33 \\
\hline
\end{tabular}

Tablo 3'e göre anket çalışmasına katılan tasarımcıların \%60’ının sürdürülebilir moda kavramının tanımına karşılık gelen cevabı verdiği görülürken, geri kalanının ise sürdürülebilir moda kavramını yansıtan eğilimlere karşılık gelen cevaplardan herhangi birini verdikleri görülmektedir. Tanımlar içerisinde yer alan ve hızlı modanın tanımını yansıtan "Giyim sektöründe üretim yapmakta olan işletmelerin sürekli değișen, dinamik ve hızlı olması" cevabını ise hiçbir tasarımcı işaretlememiştir. Buradan katılımcıların sürdürülebilir moda ile hızlı moda arasındaki farkı biliyor olduğu söylenebilir.

Tablo 4'te tasarımciların ekolojik moda ve eko etiket ile ilgili düşünceleri verilmiştir.

Tablo 4. Tasarımcların ekolojik moda ve eko-etiket ile ilgili düșünceleri

\begin{tabular}{|c|c|c|c|}
\hline \multirow{2}{*}{ Görüşler } & Katılıyorum & Kararsızım & Katılmıyorum \\
\hline & $\%$ & $\%$ & $\%$ \\
\hline $\begin{array}{l}\text { Giysilerin kalitesinden çok ekolojik olmasının daha } \\
\text { önemli olduğu düşüncesindeyim. }\end{array}$ & 20,00 & 46,67 & 33,33 \\
\hline $\begin{array}{l}\text { Ekolojik modayı insanlar fazla tercih etmediği için bu } \\
\text { tarz giysiler tasarlamıyorum. }\end{array}$ & 40,00 & 43,33 & 16,67 \\
\hline $\begin{array}{l}\text { Ekolojik modanın yerinde bir uygulama olduğunu } \\
\text { düșünüyorum. }\end{array}$ & 70,00 & 30,00 & - \\
\hline $\begin{array}{l}\text { Doğa ve çevre sorunlarına moda tasarımcıları dikkat } \\
\text { cekmelidir. }\end{array}$ & 80,00 & 20,00 & - \\
\hline $\begin{array}{l}\text { Moda tasarımcıları, eski giysilerden yeni giysiler } \\
\text { üreterek çevreci bir yaklașım sergilemelidirler. }\end{array}$ & 83,33 & 16,67 & - \\
\hline $\begin{array}{l}\text { Eko-etiketli ürünler tüketicinin bilincini ve bilgisini } \\
\text { arttırdığından tercih edilmesi } \\
\text { düşünüyorum. }\end{array}$ & 76,67 & 23,33 & - \\
\hline $\begin{array}{l}\text { Çalıştığım işletmede giysi geri dönüşüm kutularına } \\
\text { yer verilmektedir. }\end{array}$ & 6,67 & 16,67 & 76,67 \\
\hline $\begin{array}{l}\text { Çalıştığım işletme geri dönüşüm konusunda duyarlı } \\
\text { davranmaktadır. }\end{array}$ & 20,00 & 16,67 & 63,33 \\
\hline \multirow{2}{*}{ Görüşler } & Evet & Hayır & Bazen \\
\hline & $\%$ & $\%$ & $\%$ \\
\hline $\begin{array}{l}\text { Çalıştığım yer çevre dostu ürünler üzerine üretim } \\
\text { yapmaktadır. }\end{array}$ & 10,00 & 80,00 & 10,00 \\
\hline $\begin{array}{l}\text { Ekolojik modaya uygun giysiler giymeye özen } \\
\text { gösteriyorum. }\end{array}$ & - & 66,67 & 33,33 \\
\hline $\begin{array}{l}\text { Giysi satın alırken, çevre dostu olup olmadığından } \\
\text { ziyade üzerimde duruşuna bakarım. }\end{array}$ & 20,00 & 56,67 & 23,33 \\
\hline İkinci el giysi satan mağazalardan giysi satın alırım. & 40,00 & 60,00 & - \\
\hline
\end{tabular}


Tablo 4'teki veriler göz önünde bulundurulduğunda; katılımcıların çoğunluğu ekolojik modanın yerinde bir uygulama olduğunu düşünmesine rağmen, bu tarz giysiler insanlar tarafından fazla tercih edilmediğinden dolayı ekolojik giysi tasarlamayanların oranının \%40 olduğu tespit edilmiştir. Tüketici tercihlerinin moda tasarımcılarını etkilediği görülmektedir zira bu soruya katılmıyorum cevabını verenlerin sayısı çok azdır $(\% 16,67)$. Tasarımcların çoğunluğu eko-etiketli ürünlerin tüketicilerin bilincini ve bilgisini artırdığ 1 için tercih edilmesi gerektiğini düşünmektedir.

Tasarımcların giysilerin kalitesi ve ekolojik olması durumu göz önünde bulundurulduğunda, ekolojik olmasına az sayıda tasarımcının (\%20) önem verdiği görülürken bu konuda çoğunluğun kararsız olduğu görülmektedir. Bununla birlikte çoğunluk, moda tasarımcılarının eski giysilerden yeni giysiler üreterek çevreci bir yaklaşım sergileyerek doğa ve çevre sorunlarına dikkat çekmeleri gerektiğini ifade etmiştir. Ancak ekolojik modaya uygun giysiler giymeye özen gösteren hiç tasarımcı olmadığı görülmüş olup bu tarz giyinme konusunda çoğunluğun kararsız olduğu tespit edilmiștir. Giysi satın alırlarken de giysinin çevre dostu olması mı yoksa duruşu mu önemli olduğu konusunda kararsızların çoğunlukta olduğu görülmektedir. İkinci el giysi satan mağazalardan alışveriş yapanların oranı \%40 olarak tespit edilmiştir.

Tasarımcıların çalıştığı işletmelerde çevre dostu ürünlerin üretiminin çok az olduğu sonucuna varılmıștır. İşletmelerin

büyük çoğunluğunun geri dönüşüm konusunda duyarlı davranmadığı ve geri dönüşüm kutuları barındırmadığı ortaya çlkmıştır. Halbuki işletmede meydana gelen üretim atıkları geri dönüştürülerek; hem doğal kaynakların korunması sağlanmakta hem çevrenin korunmasına katkıda bulunulmakta hem de çöp olarak nitelendirilen bu kaynaklar geri dönüşümde kullanım alanı bularak enerji tasarrufu sağlanmaktadır. Anket sonuçları işletmelerin geri dönüşüm konusunda gereken duyarlılığı göstermediğini ortaya koymuştur.

Tasarımclar açısından hızlı moda kavramının ne ifade ettiği Tablo 5'te verilmiştir.

Tablo 5. Tasarımcılara göre hızlı moda kavramı

\begin{tabular}{|l|c|}
\hline Hızlı moda kavramı & $\mathbf{\%}$ \\
\hline $\begin{array}{l}\text { Sürekli yeni ve farklı giysiler } \\
\text { tasarlamak }\end{array}$ & 10,00 \\
\hline $\begin{array}{l}\text { Taleplere kısa sürede cevap } \\
\text { vermek }\end{array}$ & 26,67 \\
\hline Firmaların fazla gelir elde etmesi & 3,33 \\
\hline Hepsi & 60,00 \\
\hline
\end{tabular}

Ankete katılan kişilerin \%10'u hızlı modanın sürekli yeni ve farklı giysiler tasarlamak olduğunu söylerken, \%26,67'si ise taleplere kısa sürede karşılık vermek olduğunu dile getirmiştir. Tasarımcıların \%3,33'ü hızlı moda için firmaların fazla gelir elde etmesi olduğunu düşünürken, katılımcıların yarısından fazlasının yani \%60'ının ise hızlı moda için bu ifadelerin hepsi şeklinde cevap verdiği saptanmıştır.

\section{Tartışma ve Sonuç}

Günümüzde yaşanan en önemli ve en büyük sorun hızlı üretim ve hızlı tüketim sonucunda oluşan doğal kaynakların hızlı tükenmesi sorunudur. Söz konusu bu hızlı üretim ile tüketimden etkilenen en önemli sektörlerden birisi ise tekstil ve hazır giyim sektörüdür. Son zamanlarda moda olgusu fazla hızlanmış olup tasarımcıdan üretici kitlesine, üreticiden tüketiciye geçiş zamanı da kısalmıştır. Ancak bu döngünün hızlı olmasından dolayı üretilen ürünlerin kalitesi düşmüş, tüketimde ve çevreye verilen zararda artış olmuştur. Bütün bu bahsi geçen 
problemler nedeniyle sürdürülebilirlik son yıllarda önem kazanmıș ve hızlı modaya alternatif bir çözüm olarak sürdürülebilir moda kavramı ortaya çlkmıştır. Bu sorunların çözümünde sürdürülebilir moda tasarımcısına önemli vazifeler düşmekte olup Türkiye'de hazır giyim işletmelerinde çalışan moda tasarımcılarına yönelik yapılan anket çalışmasında ulaşılan sonuçlar genel olarak şu şekildedir:

Tasarımcılar yavaş moda konusunda kendilerinin bilinçli olmadığını kabul etmekle birlikte sadece yarıdan az bir kısmı kendilerine bu konuda eğitim verilmesi gerektiğini düşünmektedir. Tasarımcıların yavaş moda, etik moda, ekolojik moda gibi sürdürülebilir moda kapsamında bulunan bu kavramlara ilişkin olumlu bir düşünceye sahip oldukları görülmüştür. Ancak kendi hayatlarında, giysi kullanım davranışlarında sürdürülebilir yaklaşımı pek uygulamadıkları ortaya çıkmıştır. Ankete katılan moda tasarımclarının çoğunun geri dönüşüm yoluyla yeniden giysi tasarlamayı sevmediği belirlenmiştir. Dünya'da olduğu gibi Türkiye'deki hızlı moda sistemi içerisinde zorlu rekabet koşulları göz önünde bulundurulduğunda tasarladığı ürünlerin talep görmesinin dışında diğer sorunları önemsemeyen tasarımciların çoğunlukta olduğu görülmüştür. Hızlı modanın yavaş modaya doğru değişiminde ve sürdürülebilir yaklaşımların moda ve hazır giyim sektöründe uygulanmasında tasarımcılara büyük rol düştüğünü tasarımcıların çoğu kabul etmektedir. Ancak tüketici tercihlerinin moda tasarımcılarını etkilediği de görülmüștür. Dolayısıyla daha sürdürülebilir ürünler üretmede tüketicilerin de etkisinin olduğunu söylemek gerekir. Moda tasarımcilarının yanında tüketicilerin de sürdürülebilirlik konularında bilinç ve farkındalığa sahip olmalarıyla mevcut hızlı moda sisteminin dişına çıkılabilecektir.
Sürdürülebilir yaklaşımların uygulanması konusunda tasarımcılara büyük sorumluluklar düşmektedir. Türkiye'deki üniversitelerdeki moda tasarım programlarında, sürdürülebilirlik ve sürdürülebilir modaya yönelik verilecek eğitim ve atölye çalışmalarıyla farkındalığı yüksek ve bilinçli moda tasarımcılarının yetiştirilebileceği düşünülmektedir. Üretilecek olan giysilerin ekolojik çerçevede tasarlanmasının ürünlerin tüketim döngüsünün uzatılmasında fayda sağlayacağı düşünülmektedir. Ayrıca tasarımcıların, üretilecek giysileri çok amaçlı ya da modüler tarzda tasarlayarak tüketicilerin o giysiyi uzun yıllar sıkılmadan giyebilmesini sağlayacak tasarımlar yapması ile giysilerin kullanım ömrü uzatılabilir. Yașam ömrü uzayan giysiler ile biraz da olsa doğal kaynak tüketiminin azalması düşünülmektedir.

\section{Kaynakça}

[1] Pektaş, H., Dengin, S. 2012. İkinci El Giysi Pazarları ve Türkiye'deki Durumu, Akdeniz Sanat Dergisi, Cilt 4, s. 109-112.

[2] Tekin Akbulut, A.S. 2012. Türkiye'de Etik Moda Üzerine Bir Araştırma, Akdeniz Sanat Dergisi, Cilt 4, s. 3943.

[3] Pookulangara, S., Shephard, A. 2013. Slow fashion movement: Understanding consumer perceptions - An exploratory study, Journal of retailing and consumer services, Cilt 20(2), s. 200206.

[4] Yavuz, V. 2010. Sürdürülebilirlik Kavramı ve İșletmeler Açısından Sürdürülebilir Üretim Stratejileri, Mustafa Kemal Üniversitesi Sosyal Bilimler Enstitüsü Dergisi, Cilt 7, s. 63-86.

[5] Can, Ö., Ayvaz, K.M. 2017. Tekstil ve Modada Sürdürülebilirlik, Akademik 
Sosyal Bilimler Dergisi, Cilt 1, s. 110119.

[6] Özdemir, S., Tekoğlu, O. 2013. Ekolojik Tekstil Ürünlerinde Kullanılan Hammaddeler, Akdeniz Sanat Dergisi, Cilt 4, s. 27-30.

[7] Aktan, C. 2013. Tüketici temelli moda değeri: hızlı moda sektöründe bir uygulama. Marmara Üniversitesi, Sosyal Bilimler Enstitüsü, Doktora Tezi, 310s, İstanbul

[8] Cachon, G. Swinney, R. 2011, The Value of Fast Fashion: Quick Response, Enhanced Design, and Strategic Consumer Behavior, Management Science, Cilt 57(4), s. 778-795. DOI: $10.1287 /$ mnsc.1100.1303

[9] De Brito, M.P., Carbone, V., Blanquart, C.M. 2008. Towards a sustainable fashion retail supply chain in Europe: Organization and performance, Int. J. Prod. Econ, 114, 534-553.

[10] Yüksel, C., Gürcüm, H.B. 2012. Moda Sektörünü Yavaşlatan Eğilim: Eko Moda ve Sürdürülebilirlik, Akdeniz Üniversitesi Dergisi, Cilt 4, s. 48-51.

[11] Shen, B., Wang, Y., Lo, C., Shum, M. 2012. The impact of ethical fashion on consumer purchase behavior. Journal of Fashion Marketing and Management, 16, 234-245. DOI: $10.2752 / 175174115$ X13340749707123

[12] Mangır, A.F. 2016. Sürdürülebilir Kalkınma İçin Yavaş ve Hızlı Moda, Selçuk Üniversitesi Sosyal Bilimler Meslek Yüksekokulu Dergisi, Cilt 19 41.Yıl Özel Sayısı, s.143-154.

[13] Joy, A., Sherry Jr, J. F., Venkatesh, A., Wang, J., Chan, R. 2012. Fast fashion, sustainability, and the ethical appeal of luxury brands, Fashion Theory, Cilt 16(3), s. 273-295. DOI: 10.1108/13612021211222842

[14] Göklüberk Özlü, P., Saatçığlu, K. 2015. Etik Moda Kavramı ve Tasarımcılar, İdil Sanat ve Dil Dergisi, Cilt 4, s. 87-110.
[15] Peirson-Smith, A., Evans, S. 2017. Fashioning Green Words and Eco Language: An examination of the user perception gap for fashion brands promoting sustainable practices, Fashion Practice, Cilt 9(3), s. 373-397. DOI: 10.1080/17569370.2017.1366688

[16] Fletcher, K. 2007. Slow fashion, The Ecologist, Cilt 37(5), s. 61.

[17] Alpat, E. 2012. Yavaș Moda Nedir?, Akdeniz Sanat Dergisi, Cilt 4, s. 44-47.

[18] Türkmen, N. 2009. Tekstil ve moda tasarımı açısından sürdürebilirlik ve dönüşüm. Mimar Sinan Güzel Sanatlar Üniversitesi, Sosyal Bilimler Enstitüsü, Yayımlanmamış Sanatta Yeterlilik Tezi, 182s, İstanbul.

[19] Kılıç, S. 2013. Giyim sektöründeki üretim artıklarının sürdürülebilir moda yaklaşımı ile değerlendirilmesi ve örnek bir uygulama. Gazi Üniversitesi, Eğitim Bilimleri Enstitüsü, Yüksek Lisans Tezi, 142s, Ankara.

[20] İşmal, Ö.E., Yıldırım, L. 2012. Tekstil Tasarımında Çevre Dostu Yaklaşımlar, Akdeniz Sanat Dergisi, Cilt 4, s. 9-13.

[21] Niinimäki K. 2006. Ekodesign and Textiles, RJTA, Cilt 10(3), s. 67-75.

[22] Bradley, Q. 2002. Techno Fashion. Berg, s.115.

[23] Balım, M. 2017. H\&M Değiş-Tokuş Marketini Açtı. http://blog.adgager.com/degistokus-marketi-hm/ (Erişim Tarihi: 30.04.2017).

[24] Erdil, M. 2017. Sıfır Atık Modası. http://www.hurriyet.com.tr/sifiratik-modasi-40375721 (Erişim Tarihi: 22.03.2017).

[25] Öç, B., 2013. Sürdürülebilir Tasarım: Ürün Tasarımı ve Üretimi Temelinde Malzemelerin Geri Dönüştürülmesi Bilinci. İstanbul Teknik Üniversitesi Fen Bilimleri Enstitüsü, Yüksek Lisans Tezi, 155s, İstanbul.

[26] Ecoana, Daha İyi Bir Pamuk, Geri Dönüşmüş Bir Kot: Levı's, 
B. Tiber, S. Yücel / Hazır Giyim Endüstrisinde Çalışan Tasarımcıların Sürdürülebilir Modaya Yönelik Yaklaşımları

http://www.ecoana.com/daha-iyibir-pamuk-geri-donusmus-bir-kotlevis/, (Erişim Tarihi: 8.10.2016).

[27] Eser, B., Çelik, P., Çay, A., Akgümüş, D. 2016. Tekstil ve Konfeksiyon Sektöründe Sürdürülebilirlik ve Geri Dönüşüm Olanakları, Tekstil ve Mühendis Dergisi, Cilt 23 (101), s. 44-60. DOI: $10.7216 / 1300759920162310105$

[28] Blanchard, T. Marks \& Spencer launch the world's most sustainable suit. Telegraph, 19 June 2012, http://fashion.telegraph.co.uk/colu mns/tamsin-

blanchard/TMG9340870/ Marksand-Spencer-launch-the-worldsmost-sustainable-suit.htm, (Erişim tarihi: 30.05.2018).

[29] Yeșim, İnovatif Uygulamalar, http://www.yesim.com/icerik/22/i novatif-uygulamalar/, (Erişim Tarihi: 17.1.2017).

[30] Niinimäki, K., Hassi, L. 2011. Emerging design strategies in sustainable production and consumption of textiles and clothing, Journal of Cleaner Production, Cilt 19(16), s. 1876 1883. DOI: 10.1016/j.jclepro.2011.04.020

[31] Göksel, N., Yanmaz, K. 2012. Modası Geçmiş Giysilerin Yeniden Kullanımına Yönelik Bir Araștırma, Akdeniz Sanat Dergisi, Cilt 4, s. 3438.

[32] Jung, S., Jin, B. 2014. A theoretical investigation of slow fashion: sustainable future of the apparel industry, International Journal of Consumer Studies, Cilt 38(5), s. 510519. DOI: $10.1111 /$ ijcs.12127

[33] Shen, B. 2014. Sustainable fashion supply chain: Lessons from H\&M, Sustainability, Cilt 6(9), s. 6236-6249. DOI: doi.org/10.3390/su6096236

[34] Palomo-Lovinski, N., Hahn, K. 2014. Fashion design industry impressions of current sustainable practices, Fashion Practice, Cilt 6(1) s. 87-106. DOI: $10.2752 / 175693814 X 1391696709$ 4911

[35] Ericsson A., Brooks A. 2014. African Second-Hand Clothes: Mima-te and the Development of Sustainable Fashion, Editör: Fletcher, K., Tham, M., Routledge, s. 91-99.

[36] Ayanoğlu, S.G., Ağaç, S. 2017. Sürdürülebilir Moda Kavramına Yönelik Tasarım Fikirleri 1. SDÜ ART-E Güzel Sanatlar Fakültesi Sanat Dergisi, Cilt:10, s. 252-273. DOI: $10.21602 /$ sduarte.285083 